\title{
AGRONOMIC PERFORMANCE OF INTRODUCED BANANA VARIETIES IN LOWLANDS OF RWANDA
}

\author{
S. V. GAIDASHOVA, F. KAREMERA and E. B. KARAMURA ${ }^{1}$ \\ Institut des Sciences Agronomiques du Rwanda (ISAR), ISAR-Kibungo, Ngoma district, Rwanda \\ ${ }^{1}$ Bioversity International, Uganda, P.O. Box 24384, Kampala, Uganda
}

\begin{abstract}
Most of Rwandan banana cultivars are low-yielding and susceptible to pests and diseases. High yielding and pest/disease resistant varieties have been obtained in advanced breeding centers recently. Introduction, evaluation and adoption of such varieties by local producers may be one of the options to boost yields. The objective of this study was to evaluate the agronomic performance of FHIA hybrids in lowlands of Rwanda. Completely randomised design was used with 9 treatments (varieties) and 20 replicates. Data were recorded on plant growth and yield components, banana bunchy top virus and yellow Sigatoka incidence. All hybrids matured later than local cultivars except FHIA 18 which was the earliest maturing variety. FHIA 17 and FHIA 25 matured 1 and 3 month late compared to the average cycle of the 2 local checks. However, it was compensated by high bunch weight of 53.4 and $52.3 \mathrm{~kg}$ for FHIA 17 and FHIA 25, versus 26.9 and $19.5 \mathrm{~kg}$ for Poyo and Barabeshya, respectively. FHIA 17, FHIA 25 and FHIA 18 had the highest yield of 55.7, 52.6 and $46.5 \mathrm{t} \mathrm{ha}^{-1}$ per year, respectively. Considering their resistance to fusarium wilt and yellow Sigatoka and superior agronomic performance, they may be released for Rwandan lowlands after conducting palatability tests.
\end{abstract}

Key Words: Agronomic performance, FHIA hybrids, hybrids, Musa spp.

\section{RÉSUMÉ}

La plupart de cultivars de banane Rwandais sont faible production et susceptible aux pestes et aux maladies. Les variétés à haute production et résistantes à la peste/maladie ont été obtenues récemment dans les centres de pepiniere. L'introduction, l'évaluation et l'adoption de telles variétés par les producteurs locaux peuvent être une des options pour hausser des rendements. L'objectif de cette étude était d'évaluer la performance agronomique de FHIA hybride dans des basses-terres du Rwanda. La conception complètement aléatoire a été utilisée avec 9 traitements (les variétés) et 20 copient. Les données ont été enregistrées sur la croissance de plante et les composants de rendement, bunchy de banane premier virus et l'incidence de Sigatoka jaune. Toutes les varietes hybride ont mûri plus tard que les cultivars locaux sauf FHIA 18 qui était la plus première variété à mûrir. FHIA 17 et FHIA 25 ont mûri 1 et 3 mois tard en comparant au cycle moyen des 2 contrôles locaux. Cependant, il a été compensé par le poids élévé de paquet de 53,4 et 52,3 kg pour FHIA 17 et FHIA 25, contre 26,9 et 19,5 kg pour Poyo et Barabeshya, respectivement. FHIA 17, FHIA 25 et FHIA 18 ont eu l'à haut rendement de 55,7, 52,6 et 46,5 t ha ${ }^{-1}$ par an, respectivement. Considérer leur résistance au fusarium flanche et Sigatoka jaune et la performance d'agronomique supérieure, ils pourraient être relâchés pour rwandais des basses-terres après avoir dirigé les tests de saveur.

Mots Clés: L’exécution d’agronomic, FHIA hybride, hybride, Musa spp. 


\section{INTRODUCTION}

Globally, banana and plantain (Musa spp.) are ranked the fourth most important food crop in the world after rice (Oryza sativa), maize (Zea mays) and wheat (Triticum spp.) (Frison and Sharrock, 1999). In sub-Saharan Africa, it is estimated that over 30 million people subsist on bananas as the principal source of dietary carbohydrate (Karamura et al., 1999). Rwanda is placed among the countries with the highest consumption of banana in the world (197 kg per capita per year) and annual production of 2.25 million metric tons (Frison and Sharrock, 1999). Nearly, one quarter of country's arable land is allocated to this crop (Mpyisi et al., 2000). However, banana yields are low (about $8 \mathrm{t} \mathrm{ha}^{-1}$ per year) (MINECOFIN, 2001), while production is compromised by pest and disease complex (Okech et al., 2002).

Locally grown banana varieties are susceptible to fusarium wilt, nematodes and weevil borers (Gaidashova et al., 2004; Okech et al., 2005). Productive varieties, which are resistant to pests and diseases, may be highly suitable for improving yields and increase productivity. Banana improvement research has made some advances in 1980s and early 1990s and banana breeders have released varieties originated from conventional breeding, somaclonal or field selection, which had desirable pest- or disease resistance traits (Hwang and Tang, 1996; Rowe and Rosales, 1996a; 1996b; Singh and Uma, 1996; Tomekpe et al., 1996; De Beer et al., 2004; de Oliveira e Sylva et al., 2004; Kumar et al., 2004). FHIA hybrids originated from Honduras and are known for their superior yield characteristics, resistance to fusarium wilt and leaf spot diseases and desirable adaptability traits (Rowe and Rosales, 1996a; 1996b; Orjeda, 1999). Some FHIA hybrids (AAAA, AAAB, AABB) were introduced and evaluated in many countries in Africa and world-wide in early and mid-1990s (Vigheri, 1997; Eckstein et al., 1998; Rwezaula et al., 1998; Hartman et al., 2000; Nowakunda et al., 2000). However, such evaluation has not been conducted in Rwanda. The objective of this study was to evaluate the agronomic performance of the new introduced banana cultivars in lowland environment of Rwanda.
An on-station trial was carried out from January 2002 to December 2005 at Bugarama research site of the Institute of Agricultural Sciences of Rwanda (ISAR). Bugarama plain is situated in south-west of Rwanda, at 980 meters above sea level (masl) and it receives a mean annual rainfall of $1000 \mathrm{~mm}$. Rains are bi-modally distributed with long rain season from March to May and short rain season from mid-September to November. The soil type is volcanic alluvial soil, while dominant crops are rice and banana.

Seven hybrids bred by FHIA (Fondation Hondureña des Investigaciones Agricola) were introduced by ISAR, National Banana Research Programme in January 2002 and compared with two local cultivars (Poyo and Barabeshya) for yield characteristics over two successive crop cycles. The experimental material consisted of nine varieties: FHIA 17, FHIA 18, FHIA 21, FHIA 23, FHIA25, SH 3640 and SH 3436-9 obtained from Bioversity International via Du Roi tissue culture laboratory, South Africa; Poyo (Cavendish subgroup, dessert variety) from ISAR Rubona Research Station and Barabeshya (LujugiraMutika sub-group, a cooking variety), taken from farmers fields locally. FHIA varieties were introduced in form of tissue culture plantlets, while Poyo and Barabeshya were conventional suckers. The selection of FHIA varieties for this trial was based on their superior yield and adaptability characteristics (Rwesaula et al., 1998; Oreda, 1999; Nowakunda et al., 2000), while Poyo and Barabeshya were local checks.

A completely randomised design was used with 9 treatments consisting of varieties, where each variety was replicated 20 times (one replicate was a single plant) with spacing of 3 by 3 meters. Experimental field was located in plain having flat surface and uniform soil type (deep volcanic alluvial soil). This design was selected as recommended for banana field experiments by Orjeda (1998).

Cow manure was applied at rate of $20 \mathrm{~kg}$ per hole at planting. This rate corresponds to the quantity of manure recommended by ISAR for banana plantation establishment (ISAR, 2002). No mineral fertilisers were used in this trial. All plots were mulched with rice pad (about $5 \mathrm{~cm}$ 
thickness) before the beginning of dry season (in June and January). Rice pad was available locally and used by Bugarama farmers as mulching material. Mulch thickness of $5 \mathrm{~cm}$ was reported to be efficient for soil moisture conservation (Van Asten et al., 2007). Three plants were maintained within each banana mat. De-suckering and weeding were done regularly each 1-3 months depending on necessity.

Data were recorded on plant growth and yield components, banana bunchy top virus disease (BBTV) and black Sigatoka incidence during two successive crop cycles. Plant height and girth at one meter level were recorded at flowering. Bunch weight, number of hands, number of fruits of the second hand and total fruit number were recorded at harvest. Date of flowering and harvest were recorded. Flowering time was recorded at emergence of the flag leaf and number of days from planting to flowering was counted. Maturation period was recorded as number of days from flowering to harvest. Harvest was done when the fruits' ridges were rounded. Average annual productivity was calculated from the following formula (De Beer, pers. comm.)

Yield $\left(\mathrm{t}\right.$ ha ${ }^{-1}$ per year) = Average bunch weight (tonnes) $\mathrm{x}$ Number of harvests/ year $\mathrm{x}$ Plant density ha-1

where the number of harvests per year is derived from the ratio: number of days in year/average period between two harvests (days). BBTV incidence was estimated as percentage of plants affected by the disease during two production cycles. Youngest leaf spotted was recorded at flowering to estimate yellow Sigatoka incidence.

Data were analysed using Genstat Release 4.3 software. One and two-way analyses of variance (ANOVA) were performed. Least significant difference (LSD) test was done for variables with significant difference of means.

\section{RESULTS}

Agronomic performance. Varieties showed highly significant differences $(\mathrm{P}<0.001)$ for all variables in agronomic performance (Table 1). FHIA 18 was the first variety to reach flowering stage (255 days), followed by Poyo (291 day),

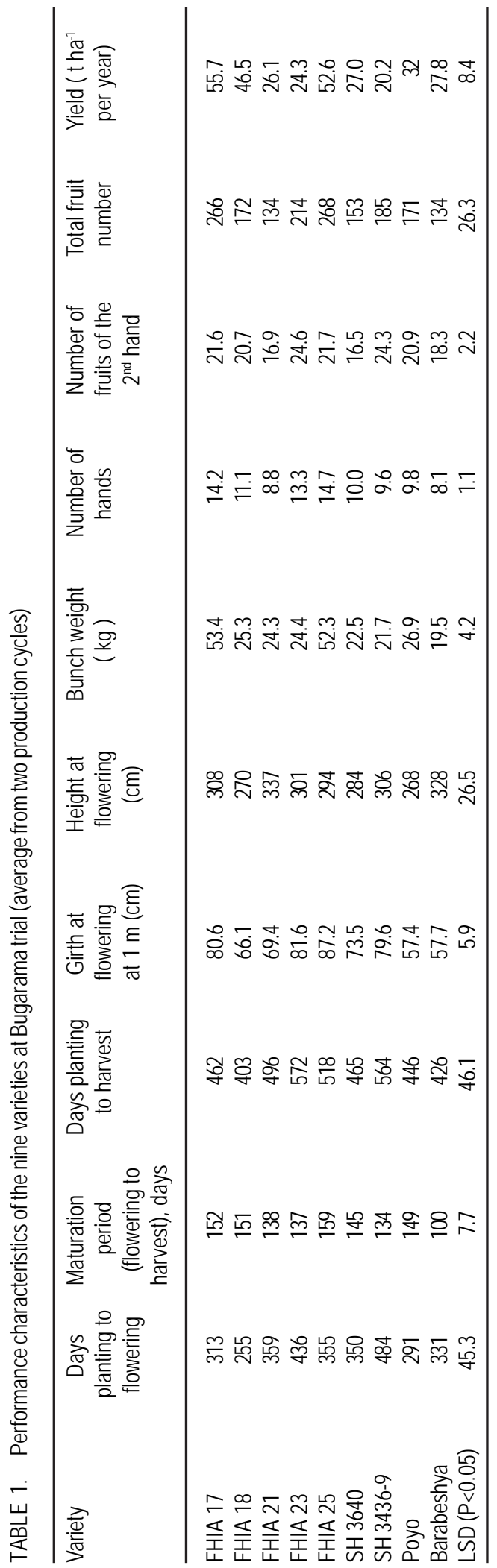


Barabeshya (313 days) and FHIA 17 (331 day). SH 3436-9 and FHIA 23 were the latest to flower with 484 and 436 days, respectively.

Local check Barabeshya had the shortest fruit maturation time of 100 days only; at least one month earlier that the fruit maturation time of other varieties (Table 1). SH 3436-9, FHIA 23 and FHIA 21 took 134, 137 and 138 days, respectively. FHIA 25 had the longest fruit maturation time of 159 days. FHIA 18 and FHIA 17 had relatively long time to maturation with 151 and 152 days, respectively.

FHIA 18 and local check Barabeshya had the shortest cycle with 403 and 426 days from planting to harvest, respectively (Table 1). FHIA 23 and SH 3436-9 had the longest cycle with 572 and 564 days to harvest, respectively. Other varieties were in intermediate positions.

Girths of pseudo-stem at one meter level of FHIA 25, FHIA 23 and FHIA 17 were the most robust with $87.2,81.6$ and $80.6 \mathrm{~cm}$, respectively. Local checks Poyo and Barabeshya were the least robust with 57.4 and $57.7 \mathrm{~cm}$, respectively.

FHIA 21 and Barabeshya were the tallest varieties with 337 and $328 \mathrm{~cm}$, respectively. Poyo and FHIA 18 were the shortest varieties with average height of 268 and $270 \mathrm{~cm}$, respectively.

FHIA 17 and FHIA 25 yielded the heaviest bunches of 53.4 and $52.3 \mathrm{~kg}$, respectively (Table $1)$. They also had the highest number of hands (14 and 15) and fruits per bunch (266 and 268, respectively). Varieties FHIA 18, FHIA 21, FHIA 23 and SH 3640 had bunch weight similar to that of Poyo (about $25.5 \mathrm{~kg}$ ). FHIA 23 and SH 3436-9 had smaller fruits, but higher number of fruits of the second hand (24.6 and 24.3, respectively).

FHIA 17, FHIA 25 and FHIA 18 had the highest annual yield (55.7, 52.6 and $46.5 \mathrm{t} \mathrm{ha}^{-1}$, respectively). They were twice more productive than Poyo and Barabeshya, both having bunch weight, close to that of FHIA 18 (Table 1). SH 3436-9, FHIA 23 and FHIA 21 had lowest yields (20.2, 24.3 and $26.1 \mathrm{t} \mathrm{ha}^{-1}$ per year, respectively). These were lower than the yield of the two local checks.

Cycle affected all measured growth and yield parameters, except the number of days from flowering to maturity. A significant $(\mathrm{P}<0.001)$ increase in girth, height, bunch weight, number of hands and fruits was observed in second production cycle for some varieties (Table 2). An increase of $20 \%$ in bunch weight was recorded in the second production cycle. However, the varieties were not uniform in bunch weight increase in the second cycle. The varieties FHIA 17, FHIA 18, FHIA 25, Poyo and SH 3640 had a significant increase in bunch weight of 21.6, 14.9, 13.8, 11.2 and $10.6 \mathrm{~kg}$ per bunch, respectively. Barabeshya, SH 3436-9 and FHIA 23 had a bunch weight increase of about $1 \mathrm{~kg}$ in the second cycle.

\section{VARIETY RESPONSE TO DISEASES}

BBTV incidence. The incidence of BBTV in the trial was $10.5 \%$. Out of 180 plants of the trial, 19 plants were affected by BBTV during two cycles, with $84.2 \%$ of the infection occurring in the first cycle. The proportion of affected plants per variety is presented in Table 3. FHIA 21 and SH 3640 had the highest proportion of affected plants (25 and 20\%, respectively). Poyo variety was not affected by the disease during the two cycles of the trial.

Yellow Sigatoka incidence. All varieties expressed highly significant $(\mathrm{P}<0.001)$ differences in their response to yellow Sigatoka (considering youngest leaf spotted records). FHIA 18, FHIA 25, FHIA 21, FHIA 17 and FHIA 23 had good leaf health with YLS of 14.3, 10.9, 10.2, 9.5 and 9.4, respectively. SH 3640 was less resistant with a YLS score of 7.5. Local checks, Poyo and Barabeshya, and SH 3436-9 were susceptible to yellow Sigatoka with YLS of 6.3, 5.6 and 4.6, respectively.

\section{DISCUSSION}

Some of the varieties performed better compared to the local checks, in terms of bunch weight and cycle duration. This resulted in higher productivity per unit of land and per year. The overall gain in annual yields was due to big bunches, as in case of the two varieties, FHIA 17 and FHIA 25, which had the highest productivity per unit of land and per year. FHIA 18, having bunch weight similar to that of Poyo, produced about 30\% more per annum due to shorter time to flowering (255 days only) from planting to harvest) compared to Poyo which was harvested 


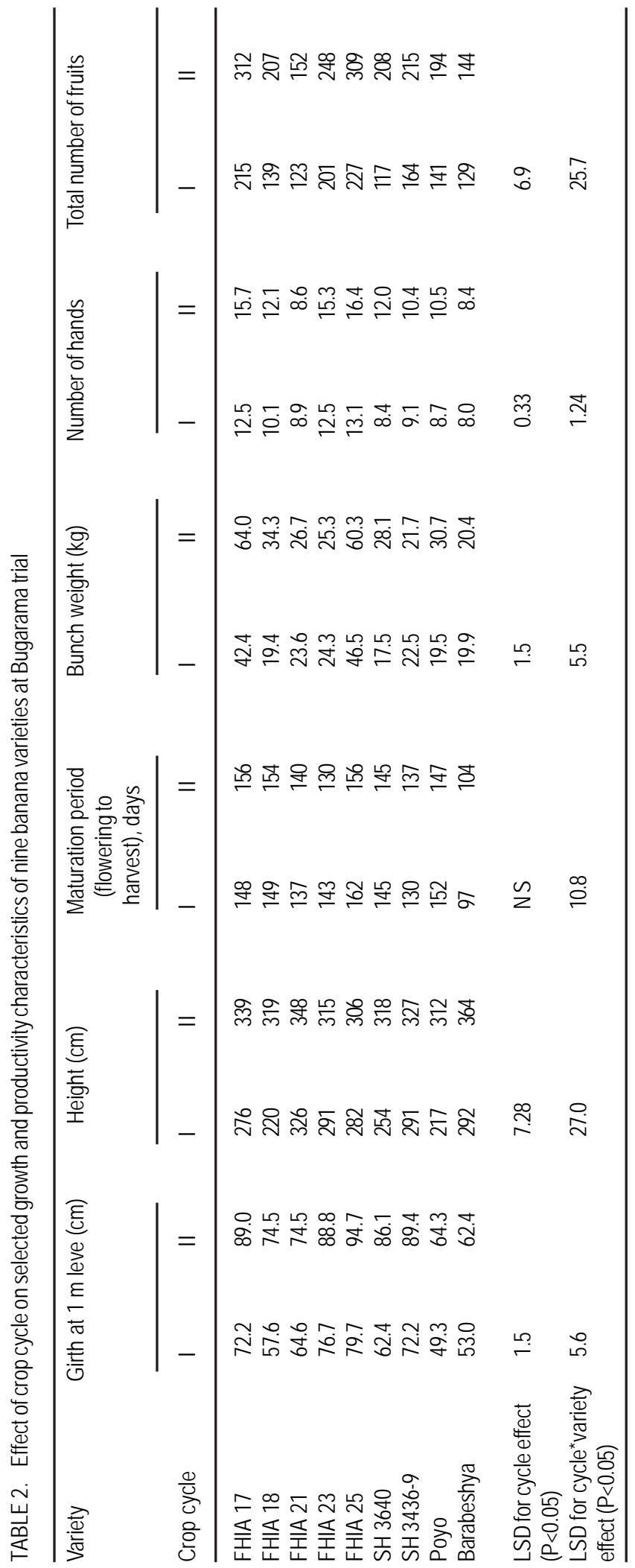


TABLE 3. Rate of BBTV infection and yellow Sigatoka incidence of nine varieties at Bugarama trial

\begin{tabular}{lcc}
\hline Variety & $\begin{array}{c}\text { Affected by BBTV plants (\%) } \\
\text { (during two cycles) }\end{array}$ & $\begin{array}{c}\text { Youngest leaf spotted } \\
\text { (average of 20 plants) }\end{array}$ \\
\hline FHIA 18 & 5.5 & 14.3 \\
FHIA 25 & 10 & 10.9 \\
FHIA 21 & 25 & 10.2 \\
FHIA 17 & 15 & 9.5 \\
FHIA 23 & 12.5 & 9.4 \\
SH 3640 & 20 & 7.5 \\
Poyo & 0 & 6.3 \\
Barabeshya & 15 & 5.6 \\
SH 3436-9 & 15 & 4.6 \\
& & \\
LSD (P<0.05) & - & 1.8 \\
\hline
\end{tabular}

33 and 68 days later in the first and second cycle, respectively (data not shown).

FHIA 23 and SH 3436-9 had the lowest annual yields due to longer periods from planting to flowering (436 and 484 days, respectively), which makes them non-desirable for small holder banana production systems.

All varieties except Poyo were affected by the BBTV during the trial period. However, any conclusion about its resistance to BBTV seems to be premature. Some varieties (FHIA 21 and SH 3640 ) were recorded to have higher incidence of BBTV than the others.

Most of the introduced varieties were resistant to black Sigatoka (with $8^{\text {th }}$ to $14^{\text {th }}$ youngest leaf spotted) compared to local checks (YLS = 5 to 6), except SH 3436-9 which was susceptible to the disease (YLS $=4$ to 5 ).

High bunch weight, short maturation time and resistance to diseases were important cultivar selection criteria highlighted by the Rwandan banana farmers (Gaidashova et al., 2005). In this regard, FHIA 17, FHIA 18 and FHIA 25, which are resistant to black Sigatoka and fusarium wilt (Orjeda, 1999), may be suitable in small holder banana systems of Rwandan lowlands with strong growth characteristics, higher yields and slightly longer (FHIA 17 and FHIA 25 only) production cycle comparing to local farmers' varieties.

\section{CONCLUSION}

Compared with Poyo and Barabeshya, FHIA 17, FHIA 18 and FHIA 25 performed better. Further evaluation of these varieties should be conducted on farm, after what they could be released for large dissemination in Rwanda. So far no tolerant or resistant varieties to BBTV were identified. Further observations on their behavior versus BBTV should be continued.

\section{ACKNOWLEDGEMENT}

The authors thank INIBAP, currently Bioversity International, for providing banana plantlets for this experiment and the Agricultural Technology Development and Transfer project of USAID for funding this research. Bioversity International has kindly facilitated the exercise of writing this manuscript.

\section{REFERENCES}

De Beer Z., Fraser, C. and Husselman, J. 2004. Resistance to Fusarium wilt of somaclonal variants (Abstract). In: Proceedings of the 1st International Congress on Musa: Harnessing research to improve livelihoods, 6-9 July, Penang, Malaysia. pp. 125. 
de Oliveira e Sylva, S., Cordeiro, Z. J. M. and Pires de Matos, A. 2004. Improved hybrids from Brazil (Abstract). In: Proceedings of the 1st International Congress on Musa: Harnessing research to improve livelihoods, 6 - 9 July, Penang, Malaysia. pp. 10.

Eckstein, K., Fraser, C., Husselman, J. and Temple Murray, N. 1998. The evaluation of promising new banana cultivars. In: Proceedings of the First International Symposium on Banana in the Sub-tropics held in Puerto de la Cruz, Tenerife, Spain, 10-14 November 1997. Ed. Galan Sauco V. Acta Horticulturae 490: 5769.

Frison, E. and Sharrock, S. 1999. The economic, social and nutritional importance of banana in the world. In: Proceedings of International symposium on bananas and food security held in Cameroon, Douala, 10-14 November 1998. Picq, C., Foure, E. and Frison, E.A. (Eds.), pp. 21-35. IPGRI.

Gaidashova, S.V., Okech, S., Van den Berg, E., Marais, M., Gatarayiha, C.M. and Ragama, P.E. 2004. Plant-parasitic nematodes in bananabased farming systems in Rwanda: species profile, distribution and abundance. African Plant Protection 10:27-33.

Gaidashova, S.V., Okech, S.H., Gold, C.S. and Nyagahungu, I. 2005. Why beer bananas: The case for Rwanda. InfoMusa 14: 2-6.

Hartman, J., Tenkouano, A. and Vuylsteke, D. 2000. Status of testing and release of improved banana and plantain cultivars in Africa. Musafrica 14: 5-6.

Hwang S. C. and Tang C. Y. 1996. Somaclonal variation and its use for improving Cavendish (AAA dessert) bananas in Taiwan. pp. 173181. In: Proceedings of the workshop on New Frontiers in Resistance Breeding for Nematode, Fusarium and Sigatoka held in Kuala Lumpur, Malaysia, 2-5 October 1995. Eds. E.A. Frison, J.-P. Horry and D. De Waele.

ISAR, 2002. Gukorera urutoki neza: imfashisho y'umuhinzi. How to grow banana: farmers' guide. ISAR ATDT-CIAT, p.14 (version Kinyarwanda), Kigali, 2002.

Karamura, E.B., Frison, E., Karamura, D.A. and Sharrock, S. 1999. Banana production systems in eastern and southern Africa. In: Picq, C., Fouré, E., Frison, E. (Eds. ). pp. 401-
412. Bananas and Food Security. Proceedings of the International Symposium, Douala, Cameroon, 10-14 November 1998, INIBAP, Montpellier.

Kumar, N., Soorianathasundaram, K., Ganga, M., Krishnamorthy, V. and Damodaran, T. 2004. Banana breeding at Tamil Nadu Agricultural University (Abstract). In: Proceedings of the 1st International Congress on Musa: Harnessing research to improve livelihoods, 6-9 July, Penang, Malaysia. pp. 11.

MINECOFIN, 2001. Rwanda development indicators. No. 4. Ministry of Economics, Finance and Planning, Kigali, 2001.

Mpyisi, E., Nyarwaya, J. B. and Shyiringiro, E., 2000. Statistiques Agricoles: production agricole, elevage, superficie et utilization des terres. Annee agricole 2000. MINAGRI-FSRPUSAID.

Nowakunda, K., Rubaihayo, P.R., Ameny, M.A. and Tushemereirwe, W. 2000. Consumer acceptability of introduced bananas in Uganda. InfoMusa 9: 22-25.

Okech, S. H. O., Gaidashova, S.V., Gold, C.S., Nyagahungu, I. and Musumbu, J.T. 2005. The influence of socio-economic and marketing factors on banana production in Rwanda: Results from a Participatory Rural Appraisal. International Journal of Sustainable Development and World Ecology 12 (2), (June 2005), 149-160.

Okech, S. H.,Gaidashova, S. V., Gold, C. S., Gatarayiha, C. and Ragama, P. 2002. Banana pests and diseases in Rwanda: A Participatory Rural Appraisal and Diagnostic Survey observations. In: Proceedings of the Integrated Pest Management Symposium, 8 to 12 September 2002, Kampala. Adipala et al.(Eds.), pp. 162-170. NARO/ Makerere University, Kampala, Uganda.

Orjeda, G. 1998. Evaluation of Musa germplasm for resistance to Sigatoka diseases and Fusarium wilt. INIBAP technical guidelines. No. 3. IPGRI, 1998.Montpellier, France. pp. 20-21.

Orjeda, G. 1999. IMTP database. INIBAP, Montpellier, France. pp. 49.

Rowe, P. and Rosales, F.E. 1996a. Current approaches and future opportunities for improving major Musa (ABB) types present 
in the Asian/Pacific region: Saba, Pisang Awak, Bluggoe. In: Proceedings of the workshop on New Frontiers in Resistance Breeding for Nematode, Fusarium and Sigatoka held in Kuala Lumpur, Malaysia, 25 October 1995. Frison, E.A., Horry, J.-P. and De Waele, D. (Eds.), pp. 129- 141.

Rowe, P. and Rosales, F.E. 1996b. Current approaches and future opportunities for improving Gros Michel (AAA dessert) bananas. In: Proceedings of the workshop on New Frontiers in Resistance Breeding for Nematode, Fusarium and Sigatoka held in Kuala Lumpur, Malaysia, 2-5 October 1995. Frison, E.A., Horry, J.-P. and De Waele, D. (Eds.), pp. 142-148.

Rwezaula, P., Hemelings, C., Gallez, A. and Sharrock S. 1998. Propagation and siffusion of improved banana varieties in the Kagera region. InfoMusa 7: 15-17.

Singh, H. P. and Uma, S. 1996. Current approaches and future opportunities for improvement of major Musa types present in Asia and the Pacific: Silk/ Pome (AAB dessert types). In: Proceedings of the workshop on New
Frontiers in Resistance Breeding for Nematode, Fusarium and Sigatoka held in Kuala Lumpur, Malaysia, 2-5 October 1995. Frison, E.A., Horry, J.-P. and De Waele, D. (Eds.), pp. 149- 163.

Tomekpe, K., Rowe, P., Tezenas du Montcel, H. and Vuylsteke, D. 1996. Plantain and Popoulou/Maia Maoli breeding: Current approaches and opportunities. In: Proceedings of the workshop on New Frontiers in Resistance Breeding for Nematode, Fusarium and Sigatoka held in Kuala Lumpur, Malaysia, 2-5 October 1995. Frison, E.A., Horry, J.-P. and De Waele, D. (Eds.), pp. 164-172.

Van Asten, P. J. A., Twagirayezu, A. and Gaidashova, S.V. 2007. Effect of Guatemala grass (Tripsacum laxum) mulch applications on soil moisture conservation and soil fertility status. Pp. 469-476. In: Proceedings of ISAR National Conference, 26-27 March 2007, Kigali, Rwanda.

Vigheri, 1997. Evaluation agronomique et resistance a la fusariose des hybrids FHIA01 et FHIA-03 au Burundi. InfoMusa 6: 2627. 